\title{
TAX BURDEN IN THE RUSSIAN FEDERATION: A COMPARATIVE ANALYSIS POINT OF VIEW
}

The article discusses the existing approaches to estimations of tax burden in Russia in comparison with the European countries. Calculations are based on the macroeconomic approach to tax bases estimations used by the European statistical service. Tax burden is evaluated by the implicit tax rates, which are the ratio of the paid taxes and macroeconomic valuation of the respective tax base. The article examines some issues in the allocation of the tax burden on corporate income, labour, and consumption; thus, the implicit tax rates on corporate income, on labour, and on final consumption in Russia and the European countries are examined. The problem of significance of the total amount of tax burden and its allocation between different categories of tax bases (corporate income, personal income, final consumption) is formulated.

It is shown that tax burden at different bases varies sufficiently and differs from the European analogues. Tax burden on corporate income and labour is not very high in comparison with most European countries. But the gap between the statutory and the implicit tax rates on corporate income is too small to provide sufficient incentives to economic actors (for long-term investments). Tax burden on labour mostly lies on employers and creates a noticeable imbalance on the national labour market.

Tax burden on consumption is very close to the highest European levels (estimated without taxes associated with exported energy products). It is shown that if the "exported part" of indirect taxes is taken into account, the burden will move to an extremely high level. The environmental tax burden in the Russian Federation is very low in comparison with the EU countries, and it is mostly created by resource taxes instead of energy taxes, as in Europe.

Keywords. Tax burden; implicit tax rate; effective average tax rate; tax competitiveness; tax burden on corporate income; tax burden on consumption.

JEL D 630, H 210, H 230, H 240

The extremely high tax burden in Russia is a commonplace in the Russian economic literature. In public opinion, has been so heavy over the past decades that it prevents economic growth and makes the national economy uncompetitive. One of the key points of the recent Russian economic policy is the evaluation of the level of tax burden. Is the existing tax burden at a rational level or higher, or is it below the reasonable or, possibly, high level? How far is it from the optimal level or from the rational one?

Modern Russian tax system is based on the same taxes as in most European countries and meets the same challenges - fairness, effectiveness, and sustainability. The tax to GDP ratio was at the level of $37 \%$ -
$38 \%$ during the past ten years, and it was not very high in comparison with France or Germany (40\%-42\%), and Denmark or Sweden $(51 \%-52 \%)$. But the Russian tax system seems to have absorbed all the existing negative features - it is far from being fair, it is not effective, and prevents any kind of economic growth.

The aim of this study is to explore whether the tax burden in Russia is too hard

\footnotetext{
${ }^{1}$ Lykova Liudmila Nikitichna, Doctor of Economics, professor, Chief Researcher, Institute of Economics, Russian Academy of Sciences, Moscow, Russia; Professor,, Chair of Tax Consulting Financial University under the Government of the Russian Federation, Moscow, Russia. (117574, Moscow, Golubinskaya St., 7-5-351); lykoval@inecon.ru
} 
or not in comparison with the key European countries.

\section{Some methodological issues}

Tax theories offer two main approaches to the estimations of the existing or preferable tax burden. The first one is within the framework of the optimal taxation theory [6; $7 ; 15]$. The second is represented by a broad scope of different comparative researches of national tax systems $[3 ; 10 ; 13]$.

The optimal taxation theories are characterized by transferring the traditional criteria of efficiency, fairness and administration into different aspects of social welfare. Thus, it is possible to make estimations of these components at the same range. This theoretical approach is convenient enough to make general recommendations for tax policy according to the dynamics of social welfare.

But most optimal taxation studies consider the total volume of tax revenue within the optimal tax system as an exogenous variable which is determined by the (necessary) government expenditures. So, the optimal tax system is designed for a certain level of tax revenue (or budget expenditures); optimal tax models could hardly be used to estimate this level. Some exemptions are presented in the endogenous growth literature $[1 ; 15]$.

Another point of view is presented by comparative analyses research in various studies of different countries' experiences. However, even the most obvious approach by using the tax to GDP fails to give a definite answer about what the optimal (or rational) tax burden should be $[3,13]$.

An analysis of tax burden as a share of the total tax revenue in the GDP is not very helpful. The analysis of the tax to GDP ratio in groups of countries according to the GDP per capita value (with the correction by the purchasing power parity) did not discover an explicit trend [9]. In each group of countries there are some with a high examined ratio and some with a low ratio. There is no explicit correlation between he tax burden (the tax to GDP ratio) and the GDP per capita value (with the PPP correction).

A hypothesis that the GDP per capita growth leads to an adequate growth of the tax to GDP ratio was examined [9]. The analysis has shown that in the countries with high GDP per capita and a high tax ratio to GDP in the previous years, when the GDP per capita figure was low, the tax to GDP ratio was, nevertheless, high [9].

In a lot of empirical research on tax competitiveness of different national jurisdictions, certain kinds of effective tax rates are used as an indicator of tax burden and tax climate attractiveness of a country.

European researchers traditionally use implicit tax rates as indicators of tax burden and tax attractiveness of different jurisdictions [ $13 ; 14$ ]. Marginal effective tax rate (METR) is also a very popular instrument of comparative analyses [See 2; 3]. METR is traditionally used to compare tax climate in different countries according to different or the same (or similar) investment projects. So, it is used in the analyses of income or corporate profit taxes and their influence on the corporate investments and decisions made by economic actors. Effective average tax rates (EATR) also give us information about the tax burden layed on the economic actors [ 8 ].

METR and EATR estimations are based on microeconomic data instead of implicit tax rates which use macroeconomic data. When microeconomic data is used in METR, estimations will provide different results, if we study tax burden in different economic spheres. It is useful mostly in choosing the exact jurisdiction for a concrete investment project. For example [ 3 ], METR in the Russian Federation (profit tax) is estimated at $30,4 \%$ according to the concrete investment project used for estimation. According to this research, the METR in 2013 in the US was $35.3 \%$, in the UK $-25.9 \%$, in Germany $24.4 \%$ and in France $-35.2 \%$.

But results may be quite different if we study another project in another economic branch or another region. Estimations made by the same authors [ 4 ] in 2010 for 2009 
show quite different results. Corporate effective tax rate on new capital investment for 2009 for the Russian Federation was estimated at $26.7 \%$. The effective tax rate was estimated at $27.7 \%$ for the United Kingdom, $24.4 \%$ for Germany, $34.4 \%$ for France, and $35.0 \%$ for US.

Another example of calculations of effective tax rates is provided by the World Bank with its Doing Business project [ 16 ]. This project presents calculations of current tax rates for a standardized company operating in the largest cities of 183 countries. The results for the Russian Federation (2013) were only $8.4 \%$ rate of profit tax. At the same time there are tax rates at $7.4 \%$ in France, $23.3 \%$ in Germany, and $20.9 \%$ in the UK.

A variety of effective tax rate studies based on microeconomic data sometimes provide incomparable results for the same country $(30.4 \%$ and $8.4 \%$ for the Russian Federation, and $35.2 \%$ and $7.4 \%$ for France).

A macroeconomic approach to estimating tax burden is presented by various Russian publications [see, for example, 9; 11]. Some research focuses on the tax potential of the composition of GDP by the type of primary incomes and the tax burden distribution between the main economic activities and brunches of industry [11].

Implicit tax rates (ITR) estimations are also based on macroeconomic data and provide information for other types of analysis. Implicit tax rates provide an instrument to analyse different aspects of tax burden - tax burden on capital, tax burden on labour, tax burden on consumption and so on. Each year Eurostat presents a report which describes the current situation with different aspects of tax burden in the European countries and Norway [14].

Implicit tax rate is the ratio of paid tax (profit or corporate income tax, individual income tax and payroll taxes, or some other taxes) to national estimation of tax base. Because each national tax system is unique (still very far from being harmonized), it is necessary to use a universal methodology of tax base information provided by National Accounts.

National wide tax base is estimated as some kind of income or expenditures according to the National Accounts system or their elements. Thus, the tax base for estimations of the implicit rate of corporate income tax will be net profit of financial and nonfinancial corporations sectors and some other points [ 14 ] from the income account (National Accounts). So, macroeconomic data are used for estimations.

This approach provides an opportunity to estimate different aspects of the tax burden in the Russian economy:

- tax burden on business (on corporate profit);

- tax burden on labour supply and demand;

- tax burden on consumption;

- tax burden of environmental taxes on the economy.

In this article we will compare implicit tax rates in the Russian Federation with those in the EU countries in the aspects mentioned above .

\section{Tax burden on corporate income}

Since after the reform of profit tax in 2001 (which came into force with Chapter 25 of The Tax Code of the Russian Federation), corporate taxation has been developing according to the liberal economic tradition. Lessee passé principle has dominated in the decision making process at the government level. As a result of the reform, the statutory tax rate has decreased from $32 \%$ to $24 \%$, and later to $20 \%$. Most tax incentives were abolished under Chapter 25 of the Tax Code. The process involved small business tax incentives, the so called investment incentives, and many others. Thus, the model of profit tax, designed at the beginning of the XXI century, was a model based on the concept of supply-side economics [ 12 ], but a very vulgar model.

Ten years later it became obvious that the state had no (or very few) tools to implement the aims of economic policy. So a new wave 
of tax incentives was started in 2009-2010: R\&D incentives, two kinds of depreciation premium; lower rates for some social services; lower rates for some regional projects and others came into force. Now, the Russian Government tries to integrate typically Keynesian tools into a liberal model of profit tax. The economic effectiveness of such a model is not very high.

The statutory profit tax rate in Russia is now one of the lowest in Europe, but the implicit tax rate on corporate income is not very low (see Fig. 1).

The implicit tax rate on corporate income is the ratio of the paid corporate income tax to the net profit of financial and nonfinancial corporations sectors according to National Accounts. The Russian system of National Accounts is still being developed, and financial accounts, some sectoral accounts and tables are in the process of being worked out. Thus, the exact implementation of the Eurostat methodology is impossible, and we have only approximate estimations.
The total volume of the tax incentives may be estimated by the leverage (the gap) between the statutory tax rate and the implicit tax rate.

The data in Figure 1 illustrate the scale of the tax rates decrease from the statutory points (adjusted) to the effective rates (estimated relative to the national wide tax base). This difference (or tax leverage) in the Russian Federation is one of the smallest in Fig 1. Tax rate in the Russian Federation falls from the statutory level of $18.8 \%$ (adjusted) to the level of $15.3 \%$ (implicit rate), that is, by 3.5 points. It is the smallest gap between the statutory and implicit rates in Fig 1. For Sweden, tax leverage is also small, but it is higher than in Russia. The statutory tax rate (adjusted) in Sweden is $26.3 \%$, and implicit rate is $20.8 \%$. So, the leverage is $4.4 \mathrm{pp}$.

The size of tax leverage in other countries is more sufficient. For example, in Germany the size of tax leverage is 11.8 points (See Graph 1), and in the Netherlands it is 18.2 points. Ireland has a very low statutory tax

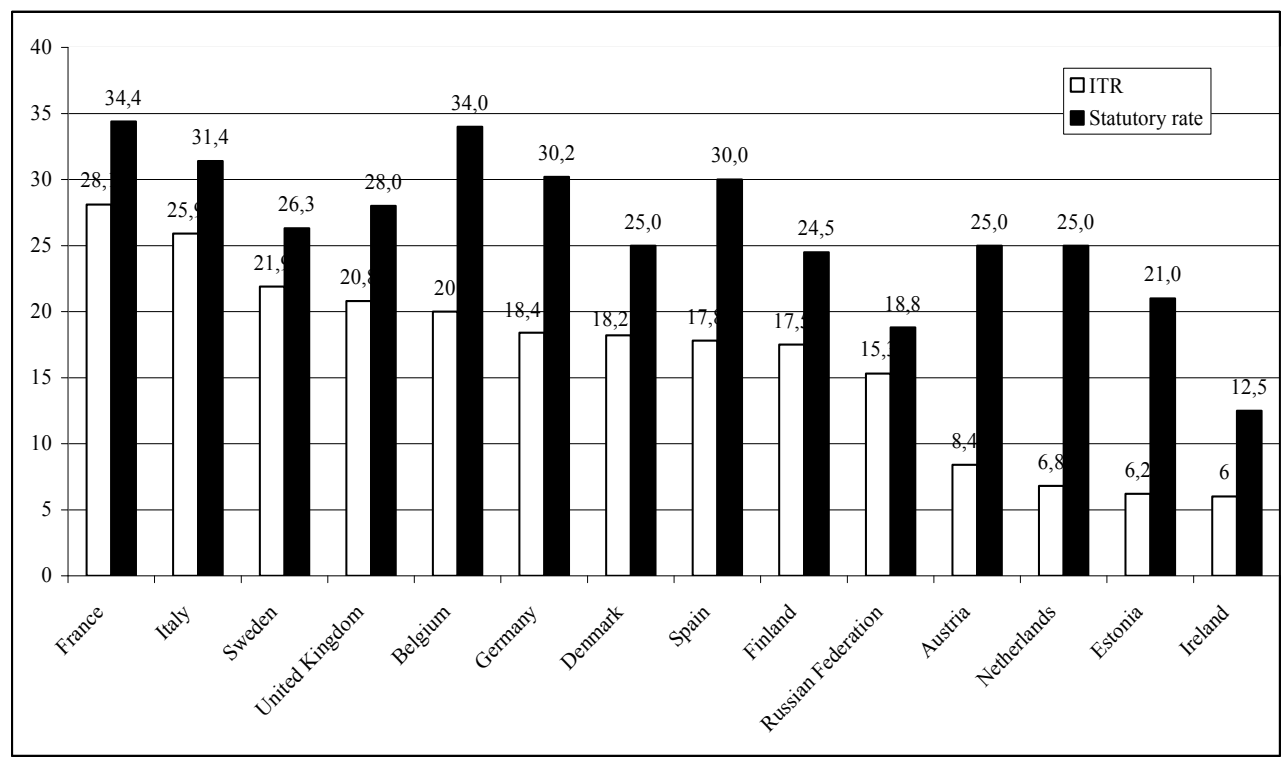

Figure 1. The statutory ${ }^{2}$ and implicit tax rates in the Russian Federation and select European countries, 2012

Source: [14, P.286]. For the Russian Federation - author's estimations based on official data (www.gks.ru).

\footnotetext{
2 Statutory tax rates here are adjusted (or weighed). Some countries impose more than one tax rate (Russia, for example) or use a progressive tax rates scale.
} 
rate $(12.5 \%)$, but the absolute size of tax leverage in this country is larger than in the Russian Federation -6.5 points against Russia' 3.5 points.

Interestingly, the statutory tax rate in Russia is one of the lowest; only Ireland has a lower rate. But the picture of implicit tax rates is quite different. There are several countries with lower implicit tax rates; they are Estonia, the Netherlands, and Austria. But most of the countries in Fig. 1 have implicit tax rates on a level higher than in Russia. In Denmark the implicit tax rate (corporate profit tax rate) is on the level of $18,2 \%$, and in Finland on the level of 17,5\%.

There are several countries where the implicit rates are higher than the statutory Russian tax rate. For example, the implicit rate in France is $28,1 \%$ in comparison with $20 \%$ statutory rate $(18.8$ adjusted statutory rate) in the Russian Federation. The same situation is observed in Italy, the United Kingdom, and Belgium, but the size of tax leverage in these countries is sufficiently larger than in Russia.
In retrospect, the implicit tax rate in Russia after 1999 has been high enough in comparison with most of the European countries (Fig. 2). Just after the profit tax reform in 2001, the tax burden (implicit tax rate) dropped from $20-21 \%$ to $15.8 \%$ in 2003 and 2004, but later the implicit tax rate went up and reached the level of $22 \%$ $23 \%$ in $2005-2008$. The next period of tax burden decrease started in 2009 with another reduction of the statutory tax rate as an anticrisis measure.

The implicit tax rate reached the highest level in $2004-23.2 \%$. The tax leverage was not stable during this period, eitrher. Just before the reform the gap between the statutory tax rate and the implicit tax rate was more the $11 \mathrm{pp}$. After the reform in 2009 , it fell to $8 \mathrm{pp}$. and declined to less than $2 \mathrm{pp}$. in the years before the financial crisis of 2008-2009. The recent situation shows some increase of tax leverage because of the drop of the implicit tax rate in 2009-2010 as a result of focused efforts to provide tax incentives.

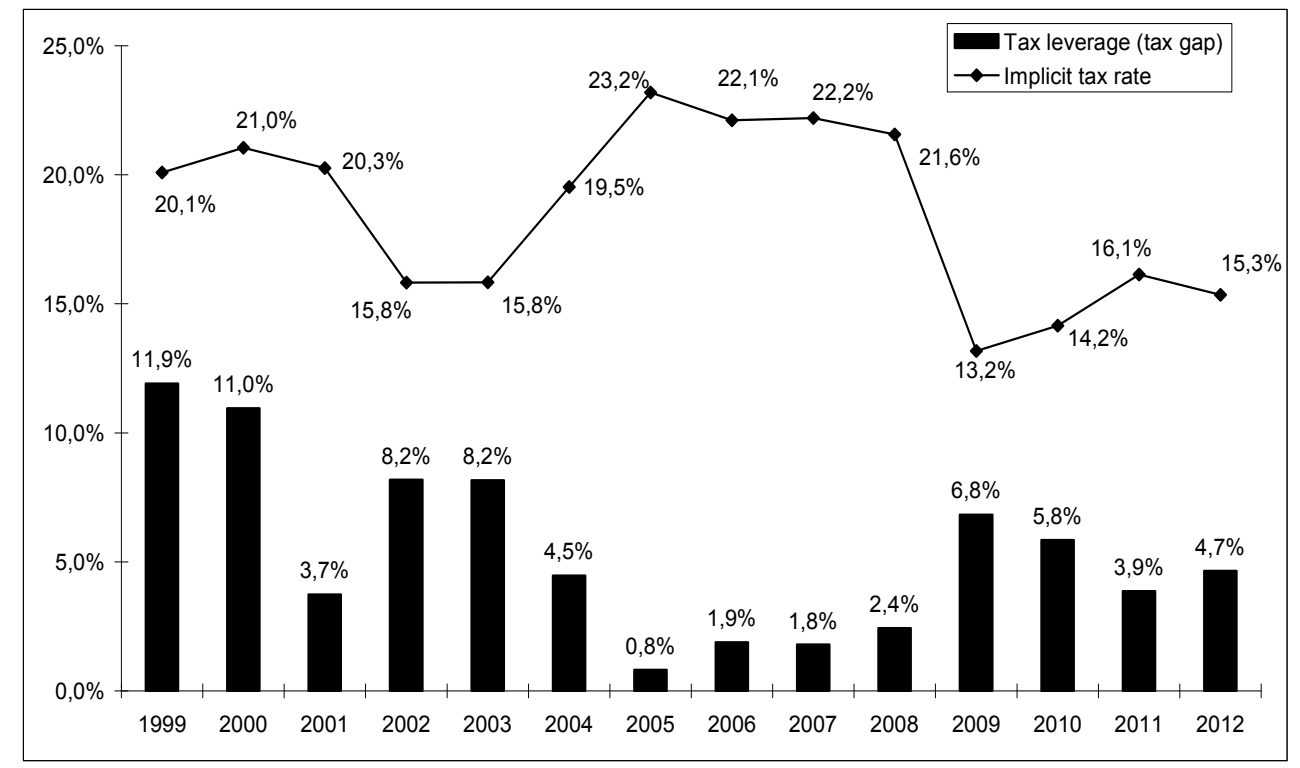

Figure 2. Implicit tax rate (corporate income) in Russian Federation Source: Author's estimations based on official data (www.gks.ru). 
To summarise, the tax burden of corporate profit tax in Russia is not too high according to the implicit tax rate, but the tax incentives potential (or tax leverage) is very small in comparison with most European countries. The small gap between statutory and implicit tax rates in the Russian Federation is not enough to create real incentives to invest in long-term projects or assets which are necessary for economic growth.

Under such conditions, the aims of dynamic tax policy, investment activity, and economic growth are going to meet with limitations created by the existing tax profit model.

Globalization of financial markets creates a new phenomenon which essentially modifies the efficacy of national tax policy and monetary policy. Financial globalization increases the level of national company integrity in the world labour division and global financial system. A national company's behavior is now determined not only by national tax policy, but also by the global financial market and its risks, shocks and financial bubbles. The national tax and budget possibilities to regulate national company activity are sharply narrowed. As a result of the 2008-2009 financial crisis, the national tax policy regulation opportunities have been narrowed. Under such conditions, international tax competition and tax competitiveness of jurisdictions reach a novel degree.

\section{Tax burden on labour}

The tax burden on labor consists of two main elements - social security payments (or/and payroll taxes) and individual income tax. There are two important points linked with the tax burden on labour. The first one is the absolute size of the burden - how large or how hard it is in a concrete time period. The second point is the distribution of the existing tax burden between labour supply and labour demand, in other words, how the total payments are distributed between employers and employees or who bears the main part of the burden. Sometimes this problem is dis- cussed in terms of the so called «tax wedge» $[13,14]$.

The existing level of social security payments in Russia, on the one hand,creates a lot of problems for businesses, especially small ones. It is a popular belief that these payments are too hard for business and create a serious obstacle for developing any kind of economic activity in Russia. On the other hand, these payments are not sufficient to finance the pension system (Russian Pension Fund) and, de facto, the Russian Pension Fund is partly financed by the general tax revenue in form of transfer payments from the Federal Budget.

Figure 3 shows the level of tax burden on labour in the Russian Federation and the EU member countries. For estimations of tax burden, implicit tax rates have been used. The implicit tax rate on labour is the ratio of social security payments (payroll taxes, social security contributions) and individual income taxes to the total sum of compensations of employees (including social payments and taxes), according to the National Accounts. For the European countries, the Eurostat data has been used [ 14, p.256]. For the Russian Federation, the implicit tax rate was estimated as a ratio of the sum of income tax (tax on physical persons' income), special regimes taxes (simplified tax, imputed income tax, unified agrarian tax paid by physical persons, and patent system payments) and social security payments to the total sum of compensations of employees according to the National Accounts ${ }^{3}$.

According to this data, total tax burden estimated by the implicit tax rate in the Russian Federation is not so hard as in the old member-countries of the EU (Fig. 3). Moreover, the implicit tax rate on labour in Russia is essentially lower than in all of the other European countries.

The estimated implicit tax rate on labour in Russia is only $20.5 \%$ and less than half as high as in Belgium and Italy (42.8\%) and

\footnotetext{
${ }^{3}$ Official site of Federal Statistical Service data (www. gks.ru).
} 
in Austria (41,5\%). Moreover, the ITR on labour in Russia is lower in comparison with the countries - new members of the EU, such as Bulgaria, Croatia, and others. Ireland, which is traditionally considered a low tax country, also has the ITR on labour higher than in Russia.

The next issue is distribution of the tax burden between employers and employees. In 2012, in European countries employers bore $37.9 \%$ of total tax (social security contributions and payroll tax) burden, and employees bore the remaining $62.1 \%{ }^{4}$. So the main part of the total payments is laid on the supply side of the labour market. The situation in the Russian Federation is quite the opposite: the main part of the total tax burden is laid on the side of the demand in labour market. The employers paid $62.5 \%$ of the total tax and social security contributions, and employees paid $37.5 \%$.

${ }^{4}$ Authors estimations based on the data [13, pp.139140] for GDP-weighted EA-18 average.
There is another remarkable feature that distinguishes the situation in Russia from that in the European countries - the share of social security payments in the GDP; it was only $6,2 \%$ in 2012 and $6.7 \%$ in 2014 as compared with $14.6 \%$ of GDP average for EA-1 $8^{5}$.

Thus, the tax burden of labour, estimated as the implicit tax rate, is sufficiently lower in the Russian Federation than in the European countries, but the larger share of it is laid on the side of labour demand.

Social security payments are the largest source of the consolidated (enlarged) budget of the Russian Federation total revenue, but they are not enough to cover the needs of the Russian Federation Pension Fund. The question how to finance the growing demand for retirement pensions has been in focus of heated discussions over the past years.

The fact that a larger share of tax burden on labour is laid on the side of labour demand

${ }^{5}$ Authors estimations based on the data ([13, pp.139140] for EU and on the Federal Statistical Service data (www.gks.ru ) for the Russian Federation

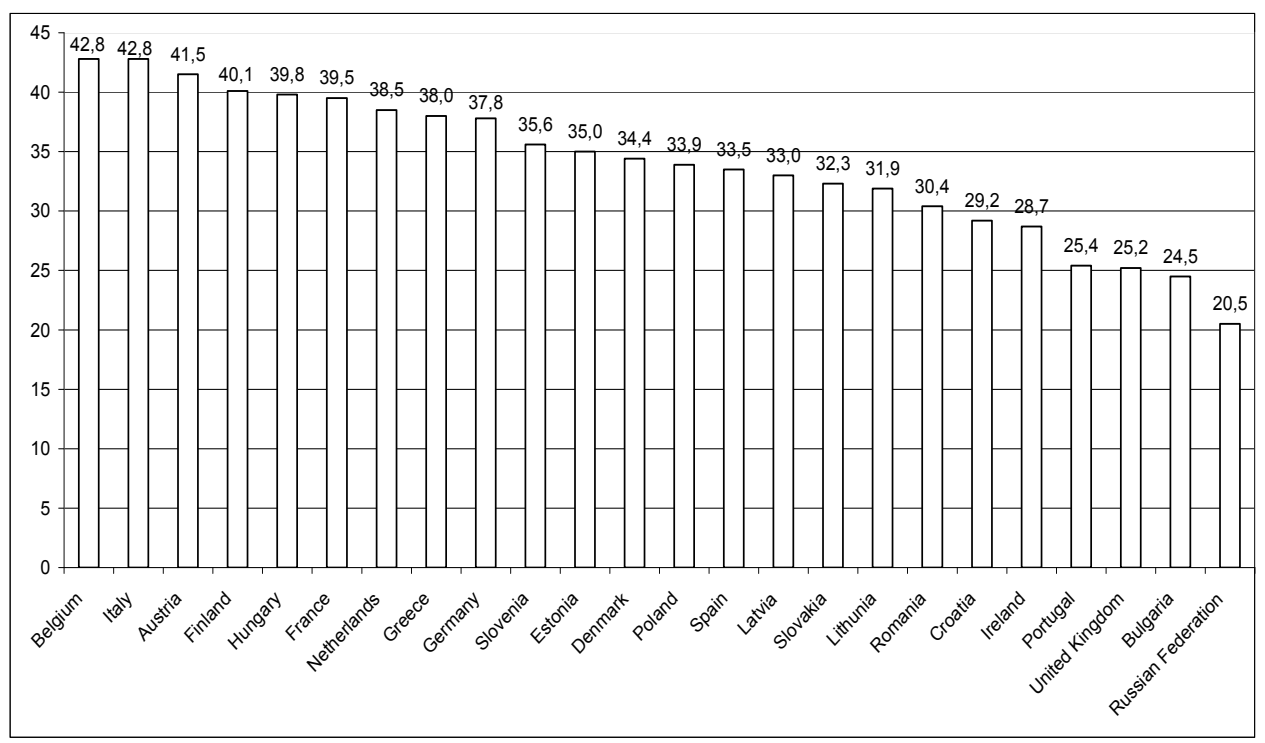

Figure 3. Implicit tax rates on labour

Source: [14. P.256]. For the Russian Federation - author's estimations based on Federal Statistical Service data (www.gks.ru). 
creates several problems in the economy. The first one is a noticeable imbalance in the labour market. This fact, along with the labour mobility, diminishes the labour market elasticity and efficiency. The second problem is the existing estimations of efficiency of labour substitution by capital. The relatively low level of the total tax burden creates zones where new European equipment and tools are considered ineffective in comparison with labour costs, so corporations prefer used, rather than new, equipment.

The third problem is tax incentives which are provided to some taxpayers by law. Under such conditions, social security contributions lose their insurance character and bring the retirement pension system back to the payas-you-go basis. The generated deficit of the Pension Fund is being continuously financed by special transfers from the Federal Budget, i.e., general tax revenue.

\section{Tax burden on consumption}

Taxes on consumption create the second largest source of revenue of the Russian budget system (after social security contributions). The burden of these payments is borne by the population. So, to estimate the size of tax burden it is necessary to compare the total sum of indirect taxes and the expenditure on final consumption of the population according to the National Accounts; it is the implicit tax rate on consumption.

The implicit tax rate (average for EU27 and EU-28) was in the range of $19.0 \%$ - 20.5\% during 1995-2012 [13, p.24-25]. The VAT accounted for $75 \%$ (in Sweden) to $56 \%$ (in Italy) of the total size of the implicit tax rate.

The Russian tax system differs from most European tax systems in that there is a severance tax (tax on extractioin of mineral resources). This tax accounted for $11.0 \%$ of the total consolidated budget revenue in 2014. The severance tax, along with VAT and excise, represent the taxes on consumption, but part of severance tax revenue is associated with the exported oil and gas and does not create a tax burden on the internal market. So, the estimations of implicit tax rates take into account only part of the severance tax associated with internal market (according to the share of oil and gas left in the country).

Russia has a high enough tax burden on consumption in comparison with the European economies (see Table 1). In 2005, ITR on consumption was below average for European countries (20.3\% against 22.3\%). In 2012 the picture was the opposite, and ITR in Russia was above the European average (23.2\% against $21.9 \%$ ). However, in both cases the difference was not very large 2 points in 2005 , and 1.3 point in 2012 .

There are no obvious trends in the country levels of ITR. Some developed economies are characterised by low level ITR on consumption. Several economies of the new EU-members also show low rates on consumption. There are old EUmembers with a low level of tax burden (the UK, Germany, France, Greece, and Spain) and some developing economies (Poland, Latvia, Lithuania and others), but there are several developed economies with high tax burden on consumption (Denmark, Norway, Sweden) and several new members (Croatia, Hungary, Estonia). So, judged by final consumption of households, the tax burden on consumption in the Russian Federation is still at the average European level.

Since 2009, VAT standard rates demonstrate a climbing trend in Europe; there are no changes in VAT rates during this period. Both standard and reduced VAT rates in Russia have not changed since 2004. On the contrary, the EU average VAT standard rate increased from $19.5 \%$ in 2009 to $21.5 \%$ in 2014 [14, p.25]. There are many European countries which increased the VAT rates to prevent a decline in revenue during the crisis (but in some countries, standard rates were reduced).

An increase in the implicit tax rate on consumption in $2005-2014$ by 2.9 points in Russia (See Table 1) was not the result of a VAT statutory rate increase. Such dynamics 
Table 1. Implicit tax rates on consumption in the EU countries and the Russian Federation, $\% \%$

\begin{tabular}{|c|c|c|}
\hline & 2005 & 2012 \\
\hline Austria & 21,7 & 21,3 \\
\hline Belgium & 22,3 & 21,1 \\
\hline Bulgaria & 21,8 & 21,5 \\
\hline Croatia & 30,0 & 29,1 \\
\hline Czech Republic & 21,1 & 22,5 \\
\hline Denmark & 33,9 & 30,9 \\
\hline Estonia & 22,0 & 26,0 \\
\hline Finland & 27,6 & 26,4 \\
\hline France & 20,3 & 19,8 \\
\hline Germany & 18,4 & 19,8 \\
\hline Greece & 15,5 & 16,2 \\
\hline Hungary & 26,1 & 28,1 \\
\hline Ireland & 26 & 21,9 \\
\hline Italy & 17,4 & 17,7 \\
\hline Latvia & 19,9 & 17,4 \\
\hline Lithuania & 16,5 & 17,4 \\
\hline Netherlands & 24,4 & 24,5 \\
\hline Norway & 29,4 & 29,4 \\
\hline Poland & 19,8 & 19,3 \\
\hline Portugal & 19,7 & 18,1 \\
\hline Romania & 17,9 & 20,9 \\
\hline Slovakia & 21,5 & 16,7 \\
\hline Slovenia & 23,5 & 23,4 \\
\hline Spain & 16,7 & 14,0 \\
\hline Sweden & 27,3 & 26,5 \\
\hline United Kingdom & 17,9 & 19 \\
\hline Average for European countries (simple) & & 21.9 \\
\hline Russian Federation & $\begin{array}{l}22.3 \\
20,3\end{array}$ & 23,2 \\
\hline
\end{tabular}

Source: [14 P.257], for the Russian Federation - the author's estimations based on the Federal Statistical Service data (www.gks.ru). 
of the total tax burden was a result of the accelerated growth of excises. The excise rate of growth in this period was higher than the rate of final consumption of households and VAT revenue rates of growth. It was the result of a political decision: during this period, the statutory excise rates were increased each year, so the excise revenue climbed 3.3 times in 2005-2012, while final consumption grew only 2.8 times.

The Russian tax system differs from most European tax systems in the great volume of customs duties. Over the past decade, customs duties have generated more than $15 \%$ of the total budget revenue, and the larger part of it is export duties (approximately 90\%). The methodological approach taken as a basis for this study gives no answer as to how to account this type of taxes. Not a single European country has met with such a problem, but in the case of Russia, this large part of the tax system and budget revenue cannot be ignored. Norway is the only European country which faces similar problems, but in case of Norway, it is not the customs duties: different kinds of fuel taxes address outside the country and associate with exported oil and gas (See [2] ).

In keeping with our methodological approach, we have to include these taxes accounting in the implicit tax rates on consumption, because they are indirect taxes. In the case of Norway, it raises the estimates of tax burden (on consumption) by 2 to 5 points [2, P.19]. If we take into account custom duties and the total sum of severance tax, in Russia the implicit tax rate will climb to $35.2 \%$, which is 12 points higher (see Table 1). But do export customs really create a tax burden on home economy and influence the purchasing power of the population?

The question remains open. Who bears the burden of customs duties (and part of severance tax in Russia), and the so called fuel taxes (in the case of Norway) within national economy?

In the case of Russia, the subjects of customs duties are Russian companies which export crude oil and oil products, that is, corporate sector and not the household sector, so a comparison of the total volume of export customs duties and the final consumption expenditures of the household sector would not be correct. Customs duties create an additional tax burden on the corporate sector, because its total hypothetical income decreases. But because the burden of these payments may be shifted to the purchaser (of the other jurisdiction), it may be seen as creating an additional burden on the corporate sector, but not on the corporate income.

The so called «tax manoeuvre» started in 2015. The aim of this political decision was to substitute a part of customs duties by the severance tax (by increasing statutory rates on oil mining), so the tax burden would be shifted from the corporate sector to the household sector, and the 12 points of the tax burden which now lie on the oil mining sector of the economy, would lie on the population (and influence its final consumption) in a few years.

\section{Environmental taxes}

Environmental taxation is a part of the indirect taxation and creates a specific segment of the total tax burden. The past decade has shown a sustainable increase in the environmental tax burden and the share of environmental taxes in the indirect taxes group in the European countries.

The definition of environmental taxes is given in the Environmental Taxes Statistical Guide [ 5]. According to this document environmental taxes include the following groups of taxes:

1. Energy taxes (taxes on energy products). Among energy products are fuel oil, natural gas, coal, petrol, and diesel, as well as electricity and some others. This group also contains the taxes on $\mathrm{CO}_{2}$ emission.

2. The group of transport taxes includes different taxes on the ownership of motor vehicles, use of motor vehicles, and import or sale of motor vehicles. It also includes 
various kinds of road taxes (only if they are not energy taxes).

3. Pollution taxes are taxes on measured or estimated emission to the air and the water (except the emission of $\mathrm{CO}_{2}$, which is considered as the base for energy taxes) .

4. Resources taxes are taxes on extraction or use of natural resources. Taxes on gas and oil extraction are not resource taxes for statistical purposes anymore. According to the 2013 Environmental Taxes Statistical Guide [5], resources taxes on oil and gas mining are not considered as environmental taxes, they are just special indirect taxes. Thus, they do not create a specific environmental tax burden.

In the case of Russia, the group of environmental taxes is as follows:

1. Excise taxes on petrol, diesel, and other oil products, and excise taxes on exported gas (since 2015). These taxes form the energy taxes group.

2. The transport taxes group is represented by transport tax and excise taxes on motor vehicles.
3. The pollution taxes group is represented by water tax and several types of the non-tax (in terms of the Russian legislation) payments, such as payments for different kinds of emission to the water and the air within the established limits or above it, payments for negative influence on the environment, payments for waste disposal, and others. The water tax also includes a part which may be considered as a tax on severance (taking water from the ground or underground sources).

4. Resources taxes are represented by the severance tax (except oil and natural gas) and the charges for using biological resources and acquatic biological resources.

Implicit tax rates could hardly be estimated for environmental taxes as a unified group. In practice, each of the above mentioned four groups has a specially determined tax base (or different bases). Only energy taxes provide an opportunity to estimate the national wide tax base - energy consumption (See 5 pp.39-40). But in the case of Russia, the official statistics used a very different methodology for energy

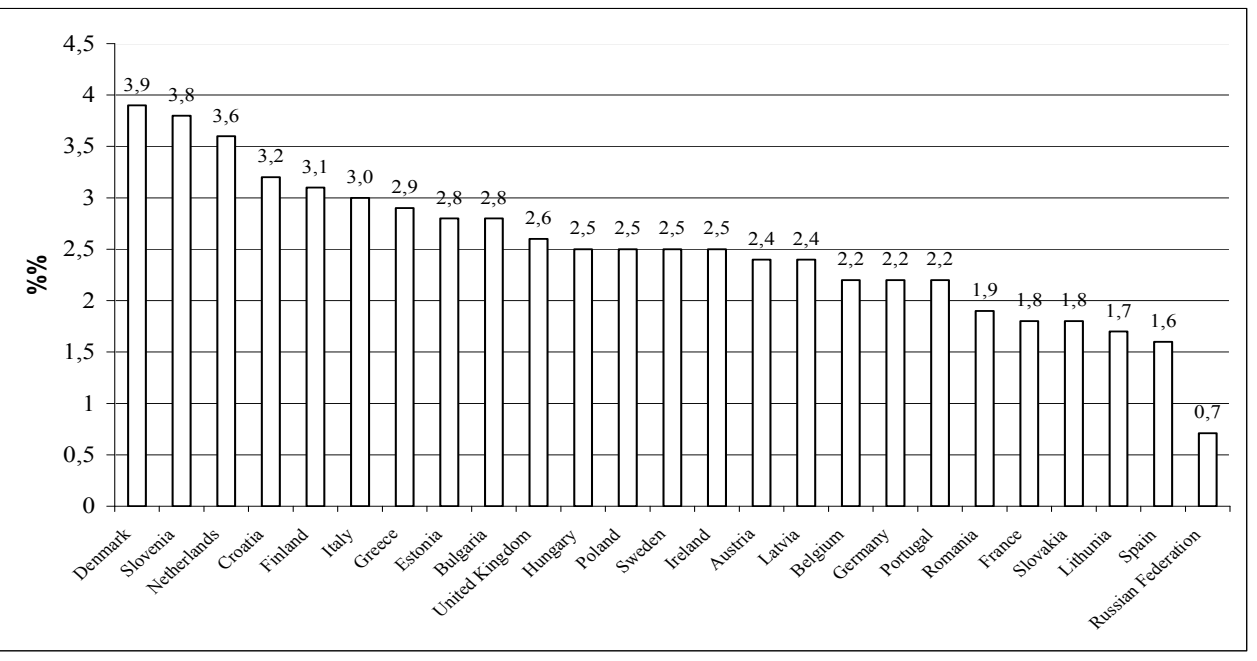

Figure 4. Environmental taxes in \%\% of GDP in the Russian Federation and some European countries (2012)

Source: [ 14, P.257], for the Russian Federation - author's estimations based on the Federal Treasury and Federal Statistical Service data (www.roskazna.ru and www.gks.ru). 
balance estimations, so estimations of implicit rates would be non-comparable.

Thus, it is possible to compare the tax burden in different countries and in the Russian Federation only by the ratio of the total sum of environmental taxes to GDP.

The total tax burden of the environmental taxes is far from being high in comparison with the European countries (see Fig. 4) it is only $0.71 \%$ of GDP in comparison with $3.9 \%$ in Denmark, $2.6 \%$ in the United Kingdom, and $1.8 \%$ in France. Environmental taxes consist mainly of energy taxes in the European countries, accounting for some $75 \%$ of EU-average. In Russia, the main part of environmental taxes is formed by resources payments (taxes and nontax payments) - 33\% (in 2012). Energy taxes create $20 \%$ of the environmental tax burden, while pollution taxes create another $18.8 \%$.

In 2014, the environmental tax burden climbed to $0.87 \%$ of GDP, but it was still sufficiently lower than in the European countries.

The total burden of environmental taxes (in comparison with GDP) provides little information about the environmental or ecological policy of a specific country or group of countries. The high level of this burden may be the result of either a very active environmental policy or inefficient energy consumption of the economy. However, the low environmental tax burden in Russia is not a consequence of inefficient energy consumption of the economy; rather, it could be attributed to the passive ecological policy of the state.

Facing acute macroeconomic and social problems, the Russian tax policy leaves the ecological and environmental problems far in the back yard. All the above mentioned taxes belong to different groups of taxes under the Russian budget classification, and all the decisions being made bear on some or several specific payments but not the environmental taxes as a unified object. This reflects the absence of an environmental tax policy as such in the Russian Federation.
It is necessary to develop an environmental tax policy of Russia that would meet contemporary ecological challenges. There are several questions to answer:

- What kind of payment should create the basis of the policy - penalties (like the modern system) or taxes?

- Are the Pigovian taxes suited for the Russian economy and its tax system?

- If the previous question is answered in the positive, should the direct model or the approximated model be used?

- Is it necessary to create special tax sources to finance environmental or ecological expenses?

The exercise of Pigovian taxes in the monopolized economy with low market elasticity would cause a shift of the tax burden from the pollution "manufacturer" to the population, with a climbing price trend. There would be no (or very little) influence on the pollution "manufacturer's" income, but the total tax burden on the final consumption would increase.

The choice between penalties and taxes is directly related to the existing profit tax model: in the case of taxes, they would tell on the profit tax base, in the case of penalties, the net after tax profit, and not the tax base, would be affected. However, in both cases the most important issue is the established pollution limits.

Any effort to create a special tax source to finance environmental or ecological programs would also increase the tax burden on the final consumption which is already high enough.

Let us draw some conclusions.

Implicit tax rates have been widely used in empirical economic analyses to compare the levels of tax burden in different countries and to follow the results of political decisions.

The European methodological approach has a limited implementation in the case of 
Russia. The Russian system of the National Accounts is still in the development stage. Financial account, some sectoral accounts and spreadsheets are still being worked out. Thus the exact implementation of the methodology is impossible, and we may have only approximate estimations.

The tax burden on corporate income in the Russian Federation is not very high in comparison with most European countries. The statutory tax rate on corporate profit is one of the lowest in Europe, but at the same time the total volume of tax incentives under this tax is limited. The tax leverage (the gap between the statutory and implicit tax rates) is very small (in comparison with the EU countries).

The tax burden on labour is also far from being high in comparison with the European countries, but a great part of this burden lies on the side of labor demand, which creates a serious misbalance (tax wedge) in the national labour market.

The tax burden on consumption in the Russian Federation is very close to the highest European levels. If we take into account the "the exported part" of this burden, it will rise to an even higher level.

The environmental tax burden is very low in comparison with the EU countries, and the larger part of this burden is created by resource taxes instead of energy taxes (as in Europe).

\section{References}

1. Barro R.J. Government Spending in a Simple Model of Endogenous Growth. Journal of Political Economy. Vol. 98, № 5 Part 2 (Oct. 1990). PP.103-125.

2. Carey D., Tchilinguirian H. Average effective tax rates on capital, labour and consumption. OECD ECO/WKP (2000) 31. Economic Department WP № 258.

3. Chan D., Mintz J. 2013 Annual Global Tax Competitiveness Ranking: Corporate tax Policy at a Crossroads / University of Calgary, The School of Public Policy Research Papers, Volume 6, Issue 35, November 2013.
4. Chan D., Mintz J., 2010. "U.S. Effective Corporate Tax Rate on New Investments: Highest in the OECD." Tax \& Budget Bulletin No. 62. Cato Institute, Washington, DC.

5. Environmental taxes. A statistical guide. Eurostat 2013 edition. European Comission. Luxemburg: Publication Office of the European Union, 2013.

6. Heady C. Optimal Taxation as a Guide to Tax Policy. A Survey. Fiscal Studies, vol. 14, №1 (Febr.1993). PP.15-41.

7. Heady C.J. A Diagrammic Approach to Optimal Commodity Taxation . Public Finance, Vol.42, 1987. PP.250-263.

8. Kubatova K. The impact of implicit rates on corporate tax revenue in EU countries./ Societas et ivrisprovdentia.

9. Lykova L.N. The tax burden in the Russian Economy: is it Excessive or Insufficient? 2014. Economy.Tax.Law. 2014.№.PP.4-11.

10. Mendoza E.G., A. Razin A. and Tesar L.L. (1994), "Effective tax rates in macroeconomics: cross-country estimates of tax rates on factor incomes and consumption", NBER Working Paper, No. 4864, September.

11. Sayfieva S. 2012.The Russian tax system: a view from the inside. The Issue of economics. 2012. № 12. PP.116-132.

12. Supply-side solution. N. Y., 1983; Supply-side Economics. Hearing before the Task Force on Tax Policy. Wash., 1981.

13. Tax Reform in EU Member States. 2014 Report. European Commission. Taxation Papers. WP №48-2014.

14. Taxation trends in the European Union. Eurostat, 2014. P.286.

15. Turnovsky S.J. Optimal Tax, Debt and Expenditure Policy in a Growing Economy. Journal of Public Economics, Vol.60, №1 (1996). PP.21-44.

16. World Bank, 2010. Doing Business 2010. The World Bank, Washington, DC., URL: http://www.doingbusiness. org/ExploreTopics/PayingTaxes. 
Л. Н. Лыкова, д. э. н., профессор , 2. Москва, Российская Федерация

\title{
НАЛОГОВОЕ БРЕМЯ В РОССИЙСКОЙ ФЕДЕРАЦИИ С ТОЧКИ ЗРЕНИЯ СРАВНИТЕЛЬНОГО АНАЛИЗА
}

\begin{abstract}
Аннотация. В статье рассматриваются существующие подходы к сравнительным оценкам налогового бремени в России и европейских странах. Проведенные расчеты базируются на макроэкономическом подходе и аналогичных оценках, публикуемых Европейской статистической службой. Налоговое бремя в рамках данного подхода определяется с помощью показателя «скрытой налоговой ставки», которая представляет собой отношение суммы уплаченного налога к макроэкономической оценке соответствующей налоговой базы. Представлены некоторые проблемы оценок распределения налогового бремени, например, исследуются значения «скрытых налоговых ставок»»» на доходы корпораций, на труд и на потребление для России и европейских стран. Рассматривается проблема существенности не только общего объема налогового бремени для экономики, но и его распределения между различными налоговыми базами (доходы корпораций, доходы физических лиц, конечное потребление). Проведенный анализ показал, что налоговое бремя на различные налоговые базы в Российской Федерации значительно различается, а также имеют место отличия от европейских аналогов. Налоговое бремя на корпоративные доходы и труд в России не является высоким в сравнении с большинством стран Европы, но разрыв между номинальной налоговой ставкой и «скрытой налоговой ставкой» для корпоративных доходов в России слишком мал для того, чтобы сформировать существенные стимулы для долгосрочных инвестиций хозяйствующих субъектов. Налоговую нагрузку на труд главным образом несут работодатели и это формирует существенный дисбаланс на национальном рынке труда. Налоговое бремя на потребление в России приближается к высоким показателям европейских стран (без учета косвенных налогов, связанных с экспортируемыми товарами). В статье показано, что учет «экспортируемой» части налогового бремени косвенных налогов смещает его масштабы на потребление в России до чрезвычайно высоких значений. Налоговое бремя экологических налогов в Российской Федерации в сравнении со странами Евросоюза довольно низко, основную часть этого бремени формируют ресурсные налоги, а в странах Европы - энергетические налоги.
\end{abstract}

Ключевые слова. Налоговое бремя; «скрытая налоговая ставка»; эффективная средняя налоговая ставка; налоговая конкурентоспособность; налоговая нагрузка на доходы корпораций; налоговая нагрузка на потребление.

\section{Сведения об авторе}

Лыкова Людмила Никитична, доктор экономических наук, профессор, главный научный сотрудник Института экономики РАН, г. Москва, Россия; профессор кафедры Налоговое консультирование Финансового университета при Правительстве Российской Федерации, г. Москва, Россия (125993, ГСП-3, г. Москва, просп. Ленинградский, 49); e-mail: lykoval@inecon.ru 